\title{
EQUAL RIGHTS FAILS AMERICAN MOTHERS: THE LIMITATIONS OF AN EQUAL RIGHTS STRATEGY IN FAMILY LAW AND THE WORKPLACE
}

\author{
MARY ANN MASON*
}

\begin{abstract}
Family law reforms in the United States over the past few decades have been impelled by an ideology of achieving equality between men and women. Despite these reforms the inequalities between American women and men, especially after breakdown of marriage, remain substantial. This article explains how these changes have worked against the interests of women. It argues that equal rights strategies overlook the significance of motherhood. In the workplace, the article argues that the integration theory, according to which the promotion of workplace equality dissolves the distinctions between male and female occupations, has failed and that a better model is the doctrine of comparable worth, which offers a non-competitive ideal of fairness or, pay equity, which recognizes the real patterns of women's working lives. The extent to which this model is followed in the United States is examined, as is the case for special recognition of the roles of mothers in other employment practices.
\end{abstract}

\section{INTRODUCTION}

While the American state legislatures failed to ratify the equal rights constitutional amendment which would have guaranteed women the equality of rights under both state and federal laws, ${ }^{1}$ substantial advances toward equal rights have been made in all areas of the law, especially family law and laws relating to employment discrimination. Indeed, many would argue that a formal constitutional amendment would be superfluous, and at best symbolic at this point in history.

Family law, which is traditionally considered the legal province of the individual states, has been completely overhauled, state by state, in the past twenty years to establish an equal rights orientation in all matters regarding divorce and custody. Employment law, has, with the introduction of the Equal Pay Act of 1963 and Title VII of the Civil Rights Act of 1964, established the federal principle of equal opportunity

* Assistant Professor, School of Social Welfare, University of California, Berkeley, California 94720, USA.

(C) Oxford University Press 1991 
for women and minorities in the workplace. The courts have been generous in interpreting the scope of these laws, and have created at least a limited framework for the concept of affirmative action as well. It is only with pay equity, or equal pay for work of equal value, where it may be argued that Congress and the courts lag behind the European Economic Community, which endorsed the concept of equality of pay for jobs of equal value in its 1975 Directive. ${ }^{2}$ But here also, progress has been made on a state by state basis, particularly through the efforts of public employee unions.

And yet, the experience of nearly thirty years of greatly expanding equal rights has by no means been completely salutary for American women. Women still earn about 64 cents to every dollar earned by men, just as they did in $1956,{ }^{3}$ before the advent of the Equal Pay Act or Title VII, and, combining their work inside and outside the home, they are working about six longer hours each week than they were in $1959 .{ }^{4}$ Moreover, the American divorce rate has nearly doubled since 1959; and divorced women are receiving less alimony and experiencing more child custody battles.

The lives of American women are significantly different from those of previous generations in two respects. They are most likely to become lifelong participants in the workforce and they are very likely to experience divorce. In both these areas the laws have turned dramatically toward equal rights. However, American women still have children in the same proportion as they have throughout this century. ${ }^{5} \mathrm{It}$ is this fact that the equal rights momentum has failed to address.

This article will analyse the development and the impact of expanding equal rights on American women in the critical areas of family law and the workplace, with some suggestions toward a new approach which incorporates the fact of motherhood into a workable strategy for women.

\section{EQUAL RIGHTS AND FAMILY LAW}

In what must be considered a revolution in family law, all states have fundamentally rewritten their divorce and custody laws since 1970.6 The two basic changes which have affected the previously protected status of mothers were the shift to no-fault divorce and an abolition of the maternal preference in custody law in combination with a strong leaning toward joint custody. ${ }^{7}$

\section{No-Fault Divorce}

Following the lead of California's revolutionary Family Law Act of 1969 all states by 1985 offered some form of no-fault divorce. ${ }^{8}$ In some states one disgruntled party may simply complain that the marriage has reached a point of irretrievable breakdown with no requirement of proof; in other states incompatibility or irreconcilable differences must be 
demonstrated if one party objects, but it is considered sufficient proof if one partner chooses to walk out and live separately for a specified period of time. In some states, living separate and apart for a period of time (from six months to three years) is deemed adequate grounds for divorce. ${ }^{9}$ The result is that in every state either the husband or the wife can leave a marriage at will.

The idea behind no-fault was to treat the marital partners as equal, autonomous adults with the ability to make their own decisions without messy court battles. The old list of grounds for divorce: adultery, physical cruelty, desertion, and mental cruelty, seemed quite out of date. Nofault was very much in keeping with judicial trends toward individual rights in decision making as expressed in the areas of privacy, ${ }^{10}$ the right to die ${ }^{11}$ and the rights of the mentally ill to reject civil commitment. ${ }^{12}$ It was also in tune with significant increase of women in the workforce and the misconception that women could now support themselves as well as men could.

The basic flaw in the no-fault model is that individuals are rarely on an equal economic footing in marriage when children enter the equation. Where there are children, one of the partners must drastically cut their participation in the workplace. ${ }^{13}$ That partner is most often the mother. She may continue to work but most often cannot compete for the highest paid jobs that require more than a forty hour regular work week. If she stays home with the children, her earning potential dissipates by the year. No fault divorce made divorce easier for both mothers and fathers, but it particularly favoured fathers by taking away the bargaining chip that was the mother's greatest asset under the fault system. Most American divorces under the fault system were not actually contested, but negotiated. To obtain freedom a man had to make a generous economic settlement for his wife and children. ${ }^{14}$ No-fault, as it developed, following the California model, gave the right of unilateral divorce, with no defense or power left to the dissenting partner.

Unilateral divorce, the no-fault model, may be fair for partners who have no children, but it usually produces severe economic hardship for the economically weaker parent, who is most often the mother. Lenore Weitzman claimed that within the first year after divorce, divorced men experience an average 42 per cent rise in their standard of living, while the standard of living for divorced women and their dependent children declines an average 73 per cent. ${ }^{15}$ Although the disparity may be less dramatic over time, as women re-partner and men acquire new commitments, the imbalance between the financial circumstances of men and women after divorce has been confirmed in world-wide studies. ${ }^{16}$ Since children most often live with their mother after divorce, they will live with the parent who is economically disadvantaged and will therefore be economically disadvantaged themselves. 


\section{Post No-Fault Property Division}

Theoretically, the egalitarian foundation of no-fault divorce does not have to apply to property division, spousal support or child support. There, social reality and common sense could dictate that fair, rather than equal, treatment would mitigate the adverse economic impact on mothers and children. In fact, property division, spousal support and child support have all been severely curtailed in the no-fault era. ${ }^{17}$ This reflects a legislative and judicial movement away from fault, the bargaining chip of the previous era, but also a movement toward equal treatment, without regard to economic reality. California led the way by removing fault as a factor in property and support awards as well as grounds for divorce, and by repudiating any gender-based differences in determining these issues. ${ }^{18}$

Fault played an important role in property division under the pre-nofault model. As the court stated in the 1946 California case, Amold v Amold, ${ }^{19}$

The rule drawn from cases hereinafter cited is that the greater the offense, the larger the proportion of the community property that must be awarded to the innocent spouse ... It obviously follows that where the divorce is granted on the more heinous grounds of adultery as well as for extreme cruelty the amount awarded to the innocent party should be greater than if granted on the ground of cruelty alone. ${ }^{20}$

The post no-fault division in California is quite different. Adhering to the strict principle of equal division of property, the main property to be divided in most cases is the family home. In the five years following the introduction of no-fault divorce the number of court orders to sell the family home rose from one in ten to one in three. ${ }^{21}$ The momentum in most states following the elimination of fault as the basis for divorce, is to eliminate it as a consideration in property division as well. Eighteen states lead this trend by expressly excluding no-fault from consideration in distributing property, while ten states are silent on the issue. ${ }^{22}$ Following the elimination of fault as a rule in dividing property, the states were left with no clear standards to follow. There is a good deal of controversy among family law scholars as to whether a community property (equal division), or an equitable (according to standards of fairness) model produces the best results for mothers and children following divorce and the issue is still unresolved in many states. ${ }^{23}$

Politically, there is a push toward equal division since it clearly represents an equal rights position. Equitable distribution, however, cuts down the rigid mandate of equal division and allows the needs of mothers and children to be addressed. The Uniform Marriage and Divorce Act, offered by the National Conference of Commissioners on Uniform State Laws, sets forth in gender-free language, equitable factors 
that may be considered: 'the age, health, station, occupation, amount and sources of income, vocational skills, employability, estate, liabilities, and needs of each of the parties, custodial provision, whether the apportionment is in lieu, of or in addition to maintenance, and the opportunity of each for future acquisition of capital assets and income'. ${ }^{24}$

\section{Post No-Fault Alimony and Child Support}

It is with alimony and child support that the mothers and children have suffered the greatest economic consequences of an equal rights orientation and its carry-over into judicial attitudes. Alimony has never been legally restricted to mothers..$^{25}$ A divorced wife with no children (at home or grown) would have rights as well as divorced wives who were also mothers. Legislative and judicial guidelines, however, before and after no-fault, considered the existence of children, at least when they were small, as a factor inhibiting the mother's ability to support herself, over and above the issue of child support. Before no-fault, the presence of children in a marriage gave more credence to the concept of life-long support.

Following no-fault there has been a relentless trend toward no alimony at all or short-term alimony for rehabilitative purposes, as opposed to life-long alimony. This trend does not consider whether the wife is raising small children. Some states specify the uppermost length of alimony; usually one or two years, and a few states severely restrict the conditions under which it may be granted at all. Indiana, for instance, allows alimony only for a 'physically or mentally handicapped spouse'. ${ }^{26}$ Although most wives did not receive alimony prior to nofault ${ }^{27}$ the percentage had fallen to 16 per cent in 1981 according to the US Census. ${ }^{28}$

Judges too often take the unfair and inaccurate position that because the law is encouraged to treat women equally, women can support themselves equally as well. This may be a fair assessment for couples where there are no children, but for marriages with children this does not reflect social and economic reality. In most marriages the mother must curtail or terminate her market activity to accommodate the needs of children. Following divorce she is given even more child rearing responsibilities as a single parent. A divorced woman is not likely to make up the economic ground she has lost. ${ }^{29}$

Child support awards have also suffered from the erroneous assumption that mothers can support themselves as well as fathers following a divorce. Between 1978 and 1981 child support awards nationally dropped by 16 per cent, and between 1983 and 1985 they dropped by another 12.4 per cent. ${ }^{30}$ On the positive side, there has been a concerted national legislative effort, in the Family Support Act of $1988,{ }^{31}$ to legally pursue non-paying fathers, who make up more than half of all divorced fathers. ${ }^{32}$ This has been assumed not simply for the sake of aiding 
mothers and children injured by divorce, but to ease the burden on the government, which must provide basic support to victims of divorce.

\section{CHILDREN FIRST}

The rapid rise in divorce and the resulting negative social consequences have stimulated many ideas for another round of divorce reforms. Few seem willing to roll back the no-fault laws and re-introduce fault as a factor in obtaining a divorce or in property division. A more attractive idea, which deals directly with the party hardest hit by divorce is a 'children first' principle which considers first of all the continuity of lifestyle of the children in matters of property division and support. ${ }^{33}$ The first step in implementing a 'children first' principle would be to rethink our unitary concept of divorce and instead divide marriages which end in divorce into at least two categories: those where there are children (at home or grown) and those where there are no children. Marriages where there are children from previous marriages will become a subset of marriages with children, with separate rules which recognize the variety of parental obligations involved. Marriages with children will have distinctly different property and support arrangements, concerned primarily with maintaining the continuity of lifestyle and well-being of the children.$^{34}$ In marriages where the children are grown, the partner who has provided the majority of caregiving and is in a weaker economic position will be equitably (not equally) compensated. This will most often be the mother.

The well-being of children is one of the factors considered in states which maintain an equitable division of property (not so in equal division, community property states), but it is not mandated as the first and primary factor. This leaves too much discretion to individual judges who can become caught up in the competing rights of the parents or the father's resources as the primary concern..$^{35} \mathrm{~A}$ children first approach will work best for mothers as well as children since their interests are most often tied to their children's, becoming the custodial parent in about 90 per cent of the divorce cases. ${ }^{36}$

\section{GUSTODY: THE ABOLITION OF MATERNAL PREFERENGE}

The move toward no-fault divorce and property settlements in the great majority of American states was based on the egalitarian assumption that women, even as mothers, are as capable of supporting themselves as men are; the move away from a maternal preference toward joint custody was based on the egalitarian assumption that fathers are interchangeable with mothers in parenting. Both of these legal reforms were passed quickly, state by state, with little or no research regarding the potential effect on children. These models met the states' desired criteria 
of equal treatment before the law between a man and a woman, but they failed to consider that mothers and fathers are not 'similarly situated'37 with regard to parenting and they failed to carefully consider the best interest of the third party, the child.

The maternal preference, or tender years doctrine, is an evidentiary presumption under the best interest principle. The best interest of the child is the rule in awarding custody, while the tender years presumption directs the court to assume that the child's best interests are served by remaining with the mother unless there is substantial evidence to the contrary. ${ }^{38}$ The age constituting 'tender years' has been left to judicial discretion, with the teen years usually considered the upper limit. This presumption was adopted by courts in almost all jurisdictions by the end of the nineteenth century. ${ }^{39}$ In the 1970s and 1980s, on the heels of nofault divorce legislation, most states rushed to eliminate the maternal preference presumption. Currently only seven states give mothers an automatic preference through case law. ${ }^{40}$ Many states rewrote their statutes regarding custody to present a gender neutral standard. In California, the law was changed in 1973 from a standard favouring maternal preference to custody 'to either parent according to the best interests of the child'.41

\section{Best Interests Standard}

For most states, the abolition of the presumption in favour of mothers as the best custodians for young children has left only the vague 'best interests of the child' guideline. Our society lacks any clear-cut national consensus on what the best interests of the child are, ${ }^{42}$ and the judge must make a determination usually based on a confusing legislative laundry list of factors to consider. ${ }^{43}$ Not only does this make it difficult for the judge to make a decision, it encourages litigation, since the determination is unpredictable.

\section{Joint Custody Rule}

A solution to the problem of choosing between legally equal parents was pushed by newly formed fathers' rights groups: a presumption in favour of joint custody ${ }^{44}$ In 1980 California again amended its Family Law Act to create this presumption, ${ }^{45}$ giving it equal footing with sole custody. With this amendment came a push toward required mediation in any custody dispute and the rule that joint custody could be judicially imposed against the wish of one parent. ${ }^{46}$ By 1988 thirty-five states followed California's lead, initiating some form of joint custody law, although not necessarily imposing it on one protesting party ${ }^{47}$ The experience in California, however, fell short of expectations. Joint custody too often became a bargaining chip where the husband threatened to ask for joint custody unless the wife agreed to drop demands for spousal support, or some other property right. Where joint 
custody was imposed it was found that the children most often live with their mother while the father is paying little or no child support. ${ }^{48}$ In 1989 it was demoted as a presumption in California, becoming just one option with the agreement of both parties. ${ }^{49}$

\section{Primary Caretaker Standard}

While joint custody does not appear likely to become a widely accepted substitute for maternal preference in determining custody disputes, the concept of the primary caretaker is gaining many followers. ${ }^{50}$ The primary caretaker is the parent who has looked after the majority of the everyday tasks of feeding, clothing, and general maintenance. As David Chambers, noted proponent of this theory has explained it: 'They should define the primary caretaker as the parent, if there is one, who has performed a substantial majority of the caregiving tasks for the child that involve intimate interaction with the child. ${ }^{.51}$ The primary caretaker theory is appealing because it theoretically treats the parents equally, although in fact, the mother turns out to be the primary caretaker in most cases. ${ }^{52}$ It is so appealing that it has won the status of a legal presumption in at least two states, Minnesota, ${ }^{53}$ and West Virginia, where the court declared in Garska v McCoy: 'Where the primary caretaker parent achieves the minimum, objective standard of behavior which qualifies him or her as a fit parent, the trial court must award the child to the primary caretaker parent' ${ }^{54}$ A study of appellate court decisions in 1982 showed that the idea of the primary caretaker has certainly caught on in determining custody disputes. A preference for the primary caretaker was second only to a stable environment in the initial determination of custody. An automatic preference for the mother was a factor cited far less frequently than a preference for the primary caretaker. ${ }^{55}$ The primary caretaker presumption has, however, been subjected to severe scrutiny by Ziff, ${ }^{56}$ who questions its suitability as a guide to predicting what may be in the best interests of the child in the future.

\section{Mothers v. Fathers}

A primary caretaker preference is presented as a gender-free alternative to 'maternal preference'. Parenthood, however, is a situation in which men and women are clearly not 'similarly situated' biologically. ${ }^{57}$ Nor are they similarly situated in terms of social reality. Biologically, the indisputable fact is that mothers give birth as fathers do not. The facts that are in dispute are whether mother and father are similarly situated following birth. Until recently, there was little dispute among scientists that the mother-child bond in young children (under five) was the focus of the young child's existence and that separation from the mother would cause severe negative effects in the way that separation from the father would not. Margaret Mead expressed the views of a 
generation of social scientists who looked at mothers and fathers across cultures:

... we should phrase the matter differently for men and women - that men have to learn to want to provide for others, and this behaviour, being learned, is fragile and can disappear rather easily under social conditions that no longer teach it effectively. Women may be said to be mothers unless they are taught to deny their child-bearing qualities. Society must distort their sense of themselves, pervert their inherent growth-patterns, perpetrate a series of learningoutrages upon them, before they will cease to want to provide, at least for a few years, for the child they have already nourished for nine months within the safe circle of their own bodies. ${ }^{58}$

In the spirit of critically examining long-held beliefs regarding differences between men and women, mother and father roles have received a great deal of attention in the past two decades. The thrust of the research which questions gender differences is not that the motherchild bond is the same as the father-child bond in our culture, but that, under different social circumstances, a father could take the role of the mother. ${ }^{59}$ Even among those researchers who believe fathers could act as mothers, few, if any, believe that there are no differences between fathers and mothers in their response to children. ${ }^{60}$ They differ on what those differences are, and how important they may be. For instance, one team of psychologists, Park and Sawin, observed fathers feeding their threeyear-olds. They observed that fathers respond to their infant's cues by adjusting the pace of feeding or the intensity of play - just as mothers do. They also observed that they rarely use this skill. When asked to demonstrate their competence for a researcher, fathers performed well, but under normal circumstances, most yield caretaking responsibility to their wives. ${ }^{61}$ This is by no means the opinion of all scientists, many of whom believe there are biological differences, hormonal and otherwise, which prepare women for giving birth and promote their strong interest in mothering. For Freudian psychologists the mother-infant attachment is still the most important relationship in the infant's life. Freud said that it was 'unique, without parallel, established unalterably as the prototype of all later love relationships'. ${ }^{2}$

This scientific controversy has confused judges and added momentum to the drive for gender neutral laws. As the New York Family Court concluded in Watts $\mathrm{v}$ Watts, ${ }^{63}$ that 'the simple fact of being a mother does not, by itself, indicate a willingness or capacity to render a quality of care different from that which the father can provide and that scientific studies show that the essential experience for the child is that of mothernig, regardless of who is performing the mothering function' ${ }^{64}$

But this scientific controversy assumes that men may wish to act like mothers whereas in fact women already are mothers and in the great majority of households perform the mothering functions. Even when 
women work outside the home, as they do in increasing numbers, they still perform far more of the child care functions than do fathers. ${ }^{65}$ Regardless of the merits of the scientific argument that fathers can, in the right circumstances, be turned into mothers, the social reality is that mothers are already mothers. It is surely in the best interests of children to recognize this social reality and guarantee the continuity of care which will be most protective of young children.

The maternal preference has another significant advantage over a primary caretaker standard. In a society where most mothers work because a father's salary cannot support a family, ${ }^{66}$ and almost all mothers work following divorce in order to survive, the identity of the 'primary caretaker' may not be clear. The actual physical caretaking of children may be, by necessity, largely in the hands of a paid caretaker, either inside or outside the home. Although, according to all studies, the mother still performs most of the caretaking tasks, ${ }^{67}$ this may not be immediately obvious to a judge. There is, in fact, evidence that many judges are critical of working mothers ${ }^{68}$ who no longer play the full-time caretaker role. For instance, the father is likely to get more parenting credit for taking the child to music lessons or to the doctor's during the daytime than the mother is for performing all the other parenting functions, but not spending the day with the child. In proportion to what is traditionally expected of mothers and fathers, the father has performed more caretaking duties and the mother fewer. With a primary-caretaker standard this could lean the decision-maker unfairly toward the father.

There are, of course, cases where the father is indeed the primary caretaker and the more nurturing parent. However, a maternal preference is a rebuttable presumption that will give way to a preponderance of evidence that demonstrates that the father has in fact been the primary caretaker and that it would be in the best interests of the child to continue this relationship. Presumably, only fathers who really function in this way will attempt to rebut the presumption, holding down the number of cases that are actually litigated.

\section{Custody Blackmail}

The abolition of the legal presumption in favour of mothers has had serious negative effects which are not immediately apparent in looking at custody statistics. ${ }^{69}$ With the application of no fault standards to property settlements, the resentments that used to be released in property disputes, now often find their vent in disputes regarding the custody of the children. Foster and Freed refer to the prevalence of 'custody blackmail ${ }^{70}$ Under a standard which declares both parents equal, and offers the loose best interest guideline, the mother can realistically be threatened with the loss of custody of a small child by a father who has no real desire for custody, but uses the threat as a way to avoid property, spousal support, or child support responsibilities. ${ }^{71}$ To avoid a custody 
contest, the frightened mother may agree to an unfair economic arrangement which will result in a lowered standard of living for herself and her children. This is certainly not protective of the rights of children. The imposition of the primary caretaker preference will not solve this problem. Unlike the maternal preference, which puts the burden on the father to prove that he is indeed more fit, the primary caretaker preference forces the mother (and the father) to compete for the preference. Where judicial discretion is paramount as it is in deciding between competing parties, the likelihood of litigation increases. Here also, as with a pure best interest standard, the threat of litigation can intimidate the mother, again leading to custody blackmail, which results in a lowered standard of living for mother and children.

Finally, custody is not an issue of equal rights between a man and woman, but rather of the competing needs of three parties: man, woman and child. In this, as in all areas of divorce where there are children, the needs of the child should come first. This is already expressed in most jurisdictions by a commitment to the 'best interest of the child'. A reintroduction of the 'maternal preference' presumption will best satisfy the child's interest.

\section{THE MARKETPLAGE AND MOTHERHOOD}

\section{The Limitations of Title VII and the EPA}

Title VII of the Civil Rights Act of 1964 was not originally intended to include women, but rather to eliminate employment discrimination against Blacks and ethnic minorities. An amendment which included sex was added almost as an afterthought. ${ }^{72}$ Although Title VII and the Equal Pay Act of $1963^{73}$ represent the major legislative weapons in women's fight for an equal position in the marketplace in America, it is clear, more than twenty-five years later, that they fall far short of that goal. ${ }^{74}$ These laws fit the equal rights model, but they fail to take into account the realities of women's work patterns. Except for the issues of pregnancy discrimination and maternity leave, the concept of motherhood or even the words children or family are very rarely, if ever, mentioned in judicial opinions or legislation relating to the workplace.

Title VII mandates that an individual's sex (gender is the more recent term), race, colour, religion or national origin shall not be grounds for discrimination in hiring, discharge, compensation, and terms of conditions of employment. ${ }^{75}$ Basically, Title VII mandates that women and minorities be given equal opportunity to compete with white males in matters relating to employment and the EPA directed that they receive the same compensation as white males when they perform equal tasks. ${ }^{76}$

Until recently, the Supreme Court liberally interpreted Title VII to the advantage of women and minorities. ${ }^{77}$ Although the law was narrowly written, with no provision for affirmative action, the court 
allowed, with restrictions, the development of this important tool. ${ }^{78}$ Even when the court took a sharply conservative turn in 1989, they offered the notable exception of Price Waterhouse v Hopkins, ${ }^{79}$ which further expanded the effectiveness of Title VII by putting the burden in some cases on the employer to show that gender discrimination was not the cause of denying promotion. ${ }^{80}$

\section{The Wage Gap and Female Occupations}

The judicial successes of Title VII, however, mask the fact that women are still doing very poorly in the marketplace compared with men. In 1956 a full-time working woman earned sixty-three cents to every dollar earned by a man. In 1986 the figure was sixty-four cents. ${ }^{81}$ There have been slight fluctuations during these thirty years, but by and large the wage gap has proved stubbornly intractable.

The most important change in the workplace is not that women are entering male dominated occupations, but that women are entering the workforce in unprecedented numbers, ${ }^{82}$ and that most of these women are working in female dominated occupations. Employed women are clustered into four industry groups with almost seventy per cent in services and retailing and state and local government. ${ }^{83}$ As the economy shifts from a manufacturing to a service base, most of the newly created jobs have gone to women. What these jobs have in common is that they are generally lower paying and less well benefited ${ }^{84}$ than jobs in the manufacturing sector. Therefore the wage gap persists.

Title VII and the EPA have been fairly successful tools for breaking down the barriers to male professions and attaining equal pay and promotions once inside, but they have been nearly useless in dealing with the low pay inequities of female dominated occupations. Title VII focuses on individual discrimination in hiring, not institutional inequities in setting pay. Employers do not often discriminate against women when they hire retail clerks, word processor operators, or nurses. They do however, offer them lower pay than male dominated occupations with similar skill. As discussed below, the courts have interpreted this wage setting as outside the range of protection of Title VII. ${ }^{85}$

\section{Integration Theory and Comparable Worth}

There are two prominent theories on how to tackle the problem of low pay in female-dominated occupations. The first is the integration theory. According to this theory, if the discrimination barriers to male occupations are removed, women will pour into male occupations. The consequent shortage of workers in female occupations will force the wages up, luring men into the jobs formerly held by women. With this free market approach, the distinctions between male and female occupations will fall naturally. ${ }^{86}$

In spite of Title VII and its expansion into affirmative action this has 
not occurred. ${ }^{87}$ The great majority of women have not entered male occupations and remain rooted in the low paying female occupations. Although more women have entered male occupations, even larger numbers have entered female occupations and the occupational profile has changed little.

The second approach to solving the problem of the persistent low wages of female occupations is to focus on elevating their low wage base rather than trying to equalize the gender make-up of the occupations. This theory has become known in America as comparable worth or pay equity. Title VII has made some inroads into integrating the work force, but there are strong reasons why most women still choose women's occupations. The largest increase of new recruits to the labour market since 1970 has been mothers. In 1970 only 27.3 per cent of women with children under the age of three was in the workforce; in 1985 it was more than 50 per cent ${ }^{88}$ Female dominated occupations provide some of the conditions that make the work lives of mothers (or fathers who are the primary caretakers) possible. For the most part they provide, as male dominated occupations often do not, regular hours, little or no overtime, and the ability to leave and return to accommodate pregnancy or the needs of children. ${ }^{89}$ There are more of these jobs closer to home and daycare.

Comparable worth, or pay equity, the popular American woman's issue of the eighties, represents a serious shift away from the integrationist goal of the seventies. It is based on a realization that, for whatever reasons, (certainly motherhood prominent among them), most women will continue to work in women's occupations rather than move into male occupations. Therefore, these occupations must be forced to pay a fair wage. The idea is technically complex, but the basic concept is that employers can and should pay wages according to the intrinsic value of a given job rather than market or other forces. The Supreme Court, in the City of Washington v Gunther, ${ }^{90}$ defined comparable worth as a theory under which plaintiffs might claim increased compensation on the basis of a comparison of the intrinsic worth or difficulty of their job with that of other jobs in the same organization or community. ${ }^{91}$ This theory is different from the EPA's 'substantially equal' work doctrine, which the Supreme Court interpreted in Corning Glass Works v Brennan ${ }^{92}$ as occurring when an employer pays unequal wages to male and female employees for equal or substantially equal work requiring equal skill, effort and responsibilities under similar working condition. The EPA, therefore, offers no relief for adjusting wages between jobs that are very different in nature. Comparing a maintenance person, for example, wth a secretary is beyond the legislative vision of the EPA.

Title VII, a far broader Act, for a while seemed to hold more promise to comparable worth advocates. There are two theories available to a plaintiff in proving a Title VII case: disparate treatment and disparate 
impact. Under a disparate treatment analysis, 'the employer simply treats some people less favorably than others because of their race, color, religion, sex or national origin'. ${ }^{33}$ Proof of a discriminatory motive or intent to discriminate is critical to a disparate treatment claim, although in some situations it may be inferred from the mere fact of differences in treatment.$^{94}$ By contrast, the disparate impact theory is not concerned with an employer's intent, but, rather, focuses on the effects of an employer's practice. ${ }^{95}$ Disparate impact occurs when an employer relies on a facially neutral practice that has a disproportionately adverse impact on members of a particular protected group. ${ }^{96}$

Thus far, attempts to force the courts to accept comparable worth as gender-based discrimination under the protective umbrella of Title VII have failed. The Supreme Court in the 1981 Gunther decision distinguished comparable worth claims from other claims of intentional discrimination which are actionable under Title VII and decided the case under other than a comparable worth theory. ${ }^{97}$ Justice Brennan particularly noted that the Court had not decided whether a comparable worth claim is sufficient to establish a prima-facie case of sex discrimination. ${ }^{98}$ To date they have still not decided, leaving the issue for the lower courts to struggle with.

The lower federal courts have been distinctly unsympathetic to comparable worth. For a brief period a Washington State District Court judge, Judge Tanner, gave hope to comparable worth proponents when he found that the existence of wage disparity, as evidenced by the job evaluation study of 15,500 male and female employees in Washington State established a prima-facie case of wage discrimination under either a disparate treatment or a disparate impact theory. ${ }^{99}$ The Ninth Circuit Court of Appeals, however, overturned the district court's ruling two years later. The reversal was on several grounds but the prominent theme that pervaded the decision was that wages that are set by the marketplace are not necessarily discriminatory on either a disparate treatment or a disparate impact theory. ${ }^{100}$ The court held: Absent a showing of discriminatory motive, which has not been made here, the law does not permit the federal courts to interfere in the market-based system for the compensation of Washington's employees. ${ }^{101}$

Other federal courts have followed a similar line of reasoning; it is not enough to demonstrate that employees of different genders receive different compensation for comparable work of equal intrinsic value. ${ }^{102}$ Rather, a plaintiff must show that there was intentional discrimination in the wage-setting. ${ }^{103} \mathrm{~A}$ showing of comparability accompanied by wage disparities is never enough unless accompanied by additional circumstantial evidence of employer's discriminatory conduct. One court ruled that female workers are permitted to seek employment in higher-paying job classifications, and wage disparities; therefore, must reflect the relative market value of the jobs. ${ }^{104}$

The courts are correct in their analysis that Title VII was not 
intended, nor can it be stretched, to cover the fundamental problem of persistently low wages in female dominated occupations. In fact, as noted, it was not originally drafted to cover the problems of women at all. ${ }^{105}$ Title VII is based on a free market model of individualistic liberty that presents the view that if the impediments of discrimination are knocked down men and women (as well as minorities) will be able to compete on equal footing. This equal competition will promote job integration ${ }^{106}$ so that women and minorities will no longer be segregated into low paying, limited clusters of jobs. With fewer women available, the former women's occupations will be forced to raise their wages, thereby attracting both men and women.

The concept of comparable worth is in direct opposition to the concept of individualistic liberty put forth by Title VII. ${ }^{107}$ Comparable worth offers a non-competitive model of fairness or equity, achieved not through competition with men in men's occupations, but by elevating the depressed wages of women's occupations. Implicit in the argument (although rarely mentioned) is the recognition that most women are not going to push to integrate male occupations. The free market model of Title VII severely limits the ability of the courts both in finding discrimination as the basis of depressed female wages and in imposing changes in the wage structure. Unless intentional discrimination can be proved under a disparate treatment theory, the courts must recognize a free market wage setting defence. Even if intentional discrimination were found, the court, following the lead of Gunther, would be unlikely to generalize their finding to support an institution-wide re-classification system, but would most probably limit their ruling to adjusting that specific job classification. ${ }^{108}$

Arguably, it is the role of the legislature, not the court, to initiate reforms which have a widespread effect on the marketplace. In fact, the idea of tampering with the so-called free market ${ }^{109}$ in order to achieve fairness is already prominent in the American system. Historically, Congress has intervened in the marketplace by setting the minimum wage, legislating child labour laws, guaranteeing collective bargaining, and passing such acts as the Fair Labor Standards Act. ${ }^{110}$ In the case of comparable worth it is the appropriate role of Congress to rectify the severe limitations of Title VII and the EPA. Since 1982 the House of Representatives has compiled voluminous testimony and congressional representatives in both houses have introduced bills on the subject during every session. ${ }^{111}$ The Reagan administration, however, following the lead of the private sector opposition, became increasingly hostile to the concept. In 1985, the Reagan-appointed Givil Rights Commission voted to reject comparable worth as a remedy for sex bias in the workplace and two months later the Equal Employment Opportunity Commission voted unanimously to reject 'pure' comparable worth cases where there was no evidence of intentional discrimination. ${ }^{112}$

In the absence of a congressional model, states have increasingly 
taken strong steps toward pay equity. By 1987, ten states had implemented some form of pay equity policies ${ }^{113}$ and twenty-eight states and 166 localities had begun comparable worth studies. ${ }^{114}$ A pay equity policy is defined as a compensation goal of equal pay for work of comparable value for state employees. These policies have been promoted by the governor, the legislature, public employee unions and women's interests groups. Their enactment has sometimes come about through state or local legislation and sometimes through labor union negotiations. ${ }^{115}$ So far their reach has been limited to public sector jobs.

Among states, Minnesota has most completely adopted and implemented a comparable worth scheme for public employees. ${ }^{116}$ Its experience serves as a model to others. In 1984 it passed a State Employees Pay Equity Act and in 1985 a Local Government Pay Equity Act. The process clearly revealed the depth of the connections between jobs and gender. Ninety per cent of the employees eligible for pay equity increases were working in thirteen occupations: secretaries, other clerical employees, teacher aides, other school aides, cooks, other food service employees, non-nursing medical employees, nurses (RN, LPN), social services employees, library employees, city clerks, clerk treasurers, and liquor store employees. The great majority of workers in these jobs were women. ${ }^{117}$ Although some of these jobs received healthy boosts in pay following reclassification, the spectre of financial doom that had been predicted by comparable worth opponents did not materialize in Minnesota. There was some variation between counties, but the average cost of implementation was 2.6 per cent of the county's payroll. ${ }^{118}$

Comparable worth is a critical strategy in closing the wage gap between men and women workers. It addresses the real pattern of women's work lives. One of the major reasons that women continue to work in female occupations is that most women at some time must balance the duties of motherhood and work, ${ }^{119}$ and often choose jobs which make this balance easier. These choices are for the benefit of children as well as mothers. It also addresses the fact that employers have exploited this choice in the past and paid women less than a fair wage. Title VII allowed this practice to continue since Title VII gives women an equal opportunity to compete for higher wages in men's occupations, but women are given no relief if they remain in women's occupations. Relief will be obtained only through strong new comparable worth legislation both at the federal and state level, eventually embracing both public and private sector jobs.

\section{Part-Time Workers}

The special demands of motherhood are most clearly evident among female part-time workers. ${ }^{120}$ The part-time workforce is made up largely of women, most of whom are primarily responsible for the care of their children. ${ }^{121}$ In 1983 the Department of Labor noted that the 'general 
profile' of part-time worker was that of a woman with school-age children who was married to a full-time worker. ${ }^{122}$ Approximately onequarter of working women work part-time, but they represent about 70 per cent of the part-time workforce. ${ }^{123}$

In addition to the fact that the majority are women, part-time workers have at least two major characteristics in common. They are paid significantly less than full-time workers on a pro rata basis, ${ }^{124}$ and they are distinctly clustered in wholesale and retail trade and service sectors in which full-time workers tend to be poorly paid. ${ }^{125}$ Most often they represent female enclaves within female occupations, sharing the experience of depressed wages that is the product of sex-based occupational segregation. In addition to earning less, part-time workers within these female-dominated occupations tend to have even less status and receive fewer benefits than full-time workers. ${ }^{126}$ A 1982 study found that only 18.59 per cent of part-time employees received health insurance, as compared to 74.3 per cent of full-time employees. ${ }^{127}$ If part-time women workers were taken into account, the wage gap between men and women would be significantly wider than it is now reported. ${ }^{128}$ However, while feminists and unions have recently devoted their attention to raising the wages of female dominated occupations through a comparable worth analysis, very little notice has been given to reforming the low wage, underbenefited structure of part-time work.

One of the explanations for the lack of attention to part-time work may be that part-time work for women is perceived as a second income, a pin money job for mothers. This perception, however, belies the economic reality of the changing wage structure, where a single wage very often can no longer support a family. ${ }^{129}$ It also does not take into account the current reality of divorce, ${ }^{130}$ which means many part-time workers are single parents and sole breadwinners. For some women the inadequacy of childcare forces them to work part-time when they would choose full-time jobs. A second explanation is that it is only recently that feminists and unions have moved away from the integrationist model of Title VII and realized that the solution for all women will not be to join male occupations. ${ }^{131}$ This acceptance should now extend to the concept of part-time work.

Title VII and the Equal Pay Act present even more limitations for reforming the part-time wage structure than they do for raising the depressed wages of full-time women workers. As discussed above, the EPA prohibits payment of lower wages to women who perform work 'substantially equal' ${ }^{\text {'32 }}$ to work performed by men in the same establishment. ${ }^{133}$ Most part-time women workers are working in female-dominated occupations where it is far more likely that they are receiving proportionally lower wages for 'substantially equal work' performed by other women, working full time, not men. This is not actionable discrimination under the EPA. If, in fact, a woman can present a prima-facie case 
that she is receiving lower wages for 'substantially equal work' performed by a man, she still must face the affirmative defences on the part of the employer that are allowed by the EPA. These specify that unequal pay is authorized if the disparity is the result of (1) a seniority system, (2) a merit system, (3) a system measuring earnings by quantity or quality of production, or (4) if the disparity is based on any factor other than sex. ${ }^{134}$

Under this fourth affirmative defence, the Department of Labor issued guidelines which presumptively excluded employees who work twenty or fewer hours from the protection of the EPA. ${ }^{135}$ This fourth defence has been the subject of a great deal of controversy, ${ }^{136}$ particularly as to how the EPA is to be integrated into a broader Title VII claim. The most recent Supreme Court decision on this issue, County of Washington $\mathrm{v}$ Gunther, however, incorporates the four affirmative defences of the EPA into Title VII. ${ }^{137}$ This leaves little hope for the part-time worker of fewer than twenty hours per week who wishes to establish a claim under the EPA or Title VII.

A comparable worth analysis under Title VII also presents particular problems for part-time workers. Traditional comparable worth analyses evaluate all full-time job classifications for both men and women workers in terms of factors such as knowledge, skill, mental and physical demands, etc and compares the wage rates. ${ }^{138}$ Comparing the jobs of part-time workers with other part-time workers is unlikely to bring relief since the great majority will be other women workers in similarly wage depressed jobs. In order to bring relief, part-time workers must be considered a subset of the full-time job grouping in which they work (if there is one). Even if this concept were established, part-time workers face the same rejection by the courts that full-time employees have experienced.

For the reasons discussed, ${ }^{139}$ the EPA and Title VII are not likely to bring relief through the courts for part-time workers. A better solution is legislation in which part-time work would be considered as a discrete part of a pay equity law. There is some legislative precedence for seeking equity with full-time workers. Congress has established pro-rated health benefit plans for federal employees, ${ }^{140}$ and in 1978 Congress passed the Federal Employees Part-time Career Employment Act of 1978. ${ }^{141}$ The Act required every federal agency to set annual goals and timetables for establishing part-time career employment positions within the federal civil service. In the eighties the interest and initiative in this issue has flagged, however, and little or no commentary appears on the subject.

Part-time work that is fairly paid and benefitted could provide an attractive solution for mothers, children, employers and society. Mothers benefit because it would allow them to earn a decent wage while better managing the obligations of family; relying less on the vicissitudes and expense of paid childcare. Children benefit because they 
would have more access to their mothers and society benefits because the children's welfare is being looked to. Employers could benefit also by having access to well-qualified employees who might otherwise stay out of the workforce entirely.

\section{THE MOMMY TRACK}

While the huge numbers of part-time women workers in female occupations have largely been ignored, there has been a growing interest in initiating a voluntary part-time track in male dominated occupations; this concept is sometimes referred to as the 'Mommy track'. ${ }^{142}$ Many women have come to realize that motherhood and the male career model are often not compatible. Rather than considering it their personal problem, women are now seeking a social solution to what is in fact a social problem. Proposals have been put forth for a reduced load work week, combined with delayed or deferred career timetables. For a woman attorney, for instance, this could mean a thirty hour (rather than a fifty to sixty hour) work week, and an indefinitely deferred partnership decision. ${ }^{143}$ She would have the option of re-joining the fast track when her child-raising responsibilities diminished.

Many feminists fear this is walking straight back into the special preference trap. By acknowledging that women need special consideration to handle motherhood, opponents of the 'Mommy track' feel that women unnecessarily take themselves out of the male competitive game. They become second string players, not likely to reach the top of their profession. There is also concern that employers will refuse to hire them at all since they require special arrangements and do not carry a 'full load'. ${ }^{144}$ For many women, however, the choice is not between getting to the top or working part-time. The choice is between working part-time or dropping out of the profession entirely. Once a player drops out of a professional, male dominated occupation, such as law, medicine or academia, the chances of re-entry anywhere close to the same level are slim. Having the option, but not the compulsion, to take a slower track can only enlarge the range of choices available for women, especially in the professions.

In the 'Mommy-track' controversy, as with others dealing with equal treatment versus special consideration, the well-being of the third party, the child, is rarely addressed. Surely it is better for a child if the mother works thirty rather than sixty hours a week. Surely it is better for a society to acknowledge this and to encourage employers to create career tracks that are not simply to accommodate women's differences, but are to support families. Fathers could be eligible for these tracks as well, avoiding the equal protection issue. This is not an issue like custody where one must lose if the other wins. In fact, however, it is far more likely that women will take advantage of these tracks more often than 
men since women remain the primary caretakers. ${ }^{145}$ The creation of part-time career tracks in male dominated professions will not come about through Title VII suits. Title VII in fact endorses the current male model of the workplace and offers relief only for those who are wrongfully barred from joining it. In the public sector, legislative initiatives such as the Federal Employees Part-time Career Employment Act of $1978^{146}$ may be expanded to include high-level management. In the private sector it will require sustained efforts on the part of organized women (and interested men) to create and institutionalize career paths that work for mothers or fathers and their children.

\section{MATERNITY/FAMILY LEAVES}

The great majority of recent arguments which pit equal consideration against special consideration in the workplace have focused on the specific act of birth, not only because that is the one issue in which there is a clear-cut physical difference between men and women which has implications in the workplace, but because, according to many feminists, it is the only incidence in which men and women differ in the workplace. Equal rights advocates attempt to minimize this difference by claiming that it is just another short-term disability. ${ }^{147}$ Congress has adopted the disability theory with the Pregnancy Discrimination Act of 1978. ${ }^{148}$ This law requires employers to make available to pregnant women only what they make available for men with short-term disabilities. This varies widely from state to state.

To treat pregnancy as a short-term disability is a mistake for both mother and child. First, it takes no notice of the baby, which should have the right of access to its mother during its first weeks. ${ }^{149}$ By refusing to consider the needs of children at birth as a workplace issue, the pattern becomes set to ignore the needs of children at all stages of their development. Childcare, flexible hours, and family sick leave become individual problems not recognized social problems of the workplace. Second, by reducing the significance of childbirth to a disability, the rights of the mother as well as the child are curtailed. Short-term disabilities are not handled in a manner that accommodates the effects of pregnancy. Benefits are usually for a few weeks in duration, and beyond that the right to return to the same or equivalent job is cancelled. ${ }^{150}$ Childbirth requires an absence of several months for the well-being of both child and mother, but this is often only available at the expense of an assured level of income maintenance, which is also needed. ${ }^{151}$ By reducing the motherhood issues in the workplace to a short period and defining it as a disability, the employer is freed from considering any other employment issues related to motherhood. Disability policies do not include family illness or family emergencies within their scope.

Considering pregnancy as a short-term disability is once again yield- 
ing to a male model of the workplace. ${ }^{152}$ This is surely to the employer's advantage since the cost of disability benefits are far less than those of a continuing family support programme. It is true that historically, employers used pregnancy as an excuse to keep women in low level jobs or to force them out of the workplace entirely. Less than thirty years ago many employers would not hire married women, or would not hire married women with children. If a woman became pregnant her choices were limited. Most often she was expected to quit, and if she did not, she was fired..$^{153}$ Many states had mandatory leave policies that were unrelated to their ability to work. If a woman insisted upon returning to work after childbirth, her hospital costs were not covered by medical insurance, her maternity leave was not covered by disability insurance or sick leave and her job was not waiting for her when she returned. ${ }^{154}$ The job she returned to, if she were allowed to return at all, would often be one with less responsibility and few advancement possibilities since she was now considered an unreliable worker.

The Pregnancy Discrimination Act amendment to Title VII, ${ }^{155}$ offers an equal treatment solution which is a limited improvement over old policies. It requires that employers provide for women only the same disability policy that they already provide for men. Very few of these policies are adequate to meet the needs of pregnancy. Most women are entitled to no more than six to eight weeks of pre- and post-natal leave, some far less. ${ }^{156}$ This can force women to return to work prematurely in order to save their job, possibly endangering their health and the health of their child. With some employers, the woman may not be allowed continuing benefits, such as medical insurance during the time of the leave. Paid leave, when it is allowed, is rarely with full pay, and usually for less time than the total leave time. For women who are a major or sole contributor of family income, this may be an intolerable burden. ${ }^{157}$

After two false starts in Geduldig v Aiello ${ }^{158}$ and General Electric Co. v Gilbert, ${ }^{159}$ the Supreme Court in Guerra moved in the correct direction when it endorsed California's maternity leave legislation giving mothers significantly more leave time with job protection than standard disability allowed. ${ }^{160} \mathrm{It}$ is, however, still a state option, and most states are not likely to be as generous. The Family Leave Act (which has been building up support in Congress for several years, but at this writing has not yet passed), ${ }^{161}$ is a mixed blessing. It recognizes childbirth as an event entitled to special consideration, but it provides no form of wage support. ${ }^{162}$ An unpaid leave is a desperate burden for many mothers. In addition, the Family Leave Act, in its effort to be gender-neutral, ignores the primary role of the mother in childbirth. Pregnancy and childbirth are not events in which mother and father can participate equally. It is the mother who must recover from the fatigue of childbirth, and it is the mother who breastfeeds the baby, if anyone does. By ignoring the 
primacy of motherhood at its beginnings, the model is set for ignoring the problems of working mothers as the child grows.

Mothers still have primary responsibility for children most of the time. Unless the conflict of work and parenting is recognized as largely a women's issue, there can be no real understanding of, or solutions to the exploitive nature of female dominated occupations and part-time work. It is women who must lead the battle to re-structure the workplace. It is desirable to design changes in the structure of the workplace which will allow fathers to participate more fully in child raising, but this should be in addition to, not at the expense of, motherhood issues.

\section{GONCLUSTON}

This brief analysis of the impact of equal rights legislation and judicial decisions in America, argues that this approach has not served American women well. Although it is difficult to make meaningful comparisons with the situation of women in other countries, it may be noted that despite the huge number of women in the workforce, America lags far behind all other industrialized countries in maternity leave, childcare, vacation time and family sick leave policy. ${ }^{163}$ American women also lag behind their European counterparts in wages compared to men. ${ }^{164}$ Just as it is difficult to compare situations between nations, it is not easy to share solutions. The American experience, however, does demonstrate the logical fallacy of a strictly equal rights approach. In an effort to abolish what they considered to be crippling stereotypes of dependent women, equal rights proponents have pushed for gender neutral laws which have too often made life needlessly difficult for mothers and children. Strictly applied equal rights work to the disadvantage of women in two ways: they deny the biological and social reality of the importance of children in women's lives, and they hold mothers to a male model of competition when they are not in an equal position to compete.

Proponents of equal rights in America argue that fathers as well as mothers share responsibility for children, and therefore children should not be the issue. ${ }^{165}$ This argument fails for three reasons. First, following twenty years of pushing toward joint parenting, American women still carry the major caretaking role (in addition to the burden of pregnancy and childbirth). Second, more than one-quarter of all children currently live in single parent families, and the single parent is the mother nine times out of ten. ${ }^{166}$ And third, gender neutral laws adopt the male model of competition in the workplace, and are not, as exemplified by Title VII, responsive to the needs of mothers and children.

While solutions are not obvious or easy, it is possible to suggest a new approach which considers the needs of mothers and children, not from an outdated stereotypic view of feminine weakness or dependence, but 
from a realistic and pragmatic assessment of what will improve the condition of their modern lives, which include both work and children.

\section{NOTES}

t The amendment first passed the senate in 1972. Ten years later, the deadline for ratification passed with only thirty-five of the required thirty-eight states having ratified.

2 For a discussion of the United Kingdom's Equal Pay Act and its amendments in the context of European Community law, see Erika Szysczak, 'Pay Inequalities and Equal Value Claims' (1985) 48 Modern Law Review, 139-57.

3 See note, 'Pay Equity or Pay Up: The Inevitable Evolution of Comparable Worth Into Employer Liability Under Title VII', 21 Loyola LAL Rev 305, $306 \mathrm{n} 2$ (1987) [hereinafter 'Pay Equity or Pay Up'].

4 Victor R. Fuchs, 'Sex Differences in Economic Well-Being' (1986) 232 Science 460.

5 C. Degler, n 8. Al Odds: Women and the Family in America 461 (1980).

6 H. Krause, Family Law in a Nutshell, 2d ed, $25 \mathrm{I}-3$ (1986). See also H. Jacob, The Silent Revolution: The Transformation of Divorce Law in the United States (1988).

7 For a thorough exposition of current family law, see Freed and Walker, 'Family Law in the Fifty States: An Overview', 21 Family Law Quarterly 417 (Winter 1988) [hereinafter 'Family Law in the Fifty States'].

${ }^{8}$ See Family Law in the Fifly States, $n 7$ above, Table I at 444.

9 'Fault grounds, however, still play an important role in divorce: divorce for fault still offers an immediate "out" in states with waiting periods for no-fault divorce. In many states, depending on which basis the divorce is obtained, marital fault still may affect the economic consequences of divorce and sometimes even questions of custody. Even where fault grounds were retained, however, the traditional defenses and bars typically were eliminated or weakened.' $H$. Krause, n 6 above at 338 .

10 The concept of a constitutionally protected right of privacy was initiated in 1965 with Griswold v Connecticut, 381 US 479 (1965).

11 'The right to die is an integral part of our right to control our own destinies, so long as the rights of others are not so affected.' Bartling v Sup Cl, 163 Cal App 3d 186, 209 Cal Rptr 220 (1984).

12 California's Lanterman Petris Short Act, which severely limited the conditions under which a mentally disordered person could be civilly committed, was passed in 1969. Cal Welf \& Inst Code Sec 5000-5599 (West 1984).

13 See Velsor and O'Rand, 'Family Life Cycle, Work Career Patterns, and Women's Wages at Midlife', 46 Jo of Marriage and Family 365 (1984).

$14 \mathrm{H}$. Krause, n 6 above at 291-2.

15 L. Weitzman, The Divorce Revolution, 323 (1985).

16 See L. Weitzman and M. Maclean, Economic Consequences of Divorce: An International Perspective (199I).

17 When fault was the sole basis for divorce, innocent wives could bargain for an economic settlement that would provide for their needs in exchange for granting the divorce. As no-fault divorce became the rule, this bargaining power was taken away, and property division is governed by specific property law. Krause, $\mathrm{n} 6$ above at 374 .

${ }_{18}$ Professor Herma Hill Kay describes the 1972 legislative hearings in California which were devoted to the subject of how to handle community property following the passage of no-fault divorce in 1969. She notes that the climate of opinion, including the drive to pass the ERA then ongoing in California, pushed for equality between the sexes. In the light of these circumstances, it is not surprising that the proponents of equal management powers for wives based their arguments primarily on the principle of equality. Hill, 'An Appraisal of California's No-Fault Divorce Law', 75 Calif L Rev 291, 302 (1987).

19 Amold v Amold, 76 Cal App 2d 877, 174 P 2d 674 (1946).

$2076 \mathrm{Cal}$ App 2d at 881-2, $174 \mathrm{P} 2 \mathrm{~d}$ at 676.

21 Weitzman, n 15 above at 31 .

22 Family Law in the Fifly States, n 7 above, Table V at 462, 463.

The states excluding fault from consideration in distributing property are: Alaska, Arizona, California, Colorado, Delaware, Illinois, Indiana, Iowa, Kentucky, Maine, Massachusetts, Minnesota, Montana, Oregon, Washington, Virgin Islands. 
Those silent on the issue of fault in property distribution are: Arkansas, Nebraska, Nevada, New Hampshire, New Mexico, North Dakota, Ohio, Oklahoma, Utah, Puerto Rico.

${ }_{23}$ Under the old law in California, that of equitable division, wives were typically awarded more than 50 per cent of the property. Under no-fault divorce law, the property distribution tends to be more equal. However, it is not clear that 'equal' distribution amounts to the same thing as fair distribution between the parties involved. The required equal division of property very often results in the sale of the family home and other assets, which may cause much disruption in the children's lives. (In contrast, the wife with custody of minor children was usually awarded the family home under the old law.) It would seem that the interests of the children are not taken into account. Under the equal division rule, the wife and children must share between themselves one-half of the marital assets, while the divorced man alone gets the other half completely for himself. Weitzman, $n$ 5 above, at 104-9, Table 9 at 74. See also H. Foster and Freed, Commentary on Equitable Distribution 26 NYL Sch L Rev 1, 47-8 (1981).

${ }_{24}$ Uniform Marriage and Divorce Act, 42 USCA, Sec 307 (West 1988).

25 Although alimony at one time was restricted to wives, it was never restricted solely to wives with children. Krause, n 6 above at 346-7.

${ }^{26}$ Family Law in the Fifty States $\mathrm{n} 7$ above at 386-7.

27 R. Eisler, Dissolution 46 (1977).

28 L. Weitzman, $\mathrm{n} 15$ above at 168 .

29 For a thorough discussion of the economic differential between men and women, caused mainly by motherhood, see $\mathrm{n} 000$ above. See also Fuchs, $\mathrm{n} 4$ above.

${ }^{30}$ New York Times, 23 August 1987, 28, cols 1, 2.

${ }^{31}$ Family Support Act of 1988, Pub L No 100-485, 102 Stat 2343 (1989).

32 Under federal law, state AFDG agencies are required to co-operate with child support enforcement agencies in locating absent parents. Parent locator services search records such as internal revenue and social security records for information on the parents' whereabouts. After the parent is located, collection may be enforced through tax return and paycheck withholding. Krause, n 6 above at $230-3$.

${ }^{33}$ Mary Ann Glendon, a leading proponent of the children first principle, states: 'All property, no matter when or how acquired, would be subject to the duty to provide for the children. Nor would there be any question of spousal support as distinct from what is allocated to the custodial spouse in his or her capacity as physical custodian. In cases where there is significant income and property left over after the children's needs have been met, the regular system of marital property division and spousal support law could be applied as a residual system'. Glendon, Abortion and Divorce in Westerm Law 95 (1987).

${ }^{34}$ Id.

35 Id.

36 Weitzman, n 15 above at 232, 237.

${ }^{37}$ In two cases, involving the exclusion of women from combat, and statutory rape laws, the US Supreme Court established a standard of constitutional review which ruled that in some circumstance, women are not similarly situated. Rostker v Goldberg, 453 US 57 (1981). Michael M. v Superior Court of Sonoma County, 450 US 464 (1981).

${ }^{38}$ Klaff, 'The Tender Years Doctrine: A Defense', 70 Calif $L$ Rev 335 (1982).

${ }^{39}$ Until this century, women did not possess equal parental rights in England and in most American jurisdictions. When mothers finally gained some of the same parental rights as fathers, the tender years doctrine began to be employed. Under the tender years doctrine, every custody dispute between parents begins with a presumption that the child would be better off in the mother's custody. In order for the father to gain custody, he must meet the prevailing standard of rebuttal and disprove the presumption. Id, at 341.

${ }^{40}$ Atkinson, 'Criteria for Deciding Custody in the Trial and Appellate Courts', 18 Fam L Q 1, 11 (1984). The seven states that give mothers an automatic preference over fathers by law are: Alabama, Florida, Kentucky, Louisiana, Mississippi, Utah, and Virginia.

41 Cal Civ Code Sec 4600 1(b) (West 1983).

42 See Mnookin, 'Child Custody Adjudication: Judicial Functions in the Face of Indeterminacy', Law and Contemporayy Problems, 226, 233 (1975).

${ }^{43}$ The Uniform Marriage and Divorce Act, Section 402, defines the child's best interest as a composite of the following variables: (1) the wishes of the child's parent or parents as to his custody; (2) the wishes of the child as to his custodian; (3) the interaction and interrelationship of the child with his parent or parents, his siblings and any other person who may significantly affect the child's best interest; (4) the child's adjustment to his home, school and community; (5) the mental and 
physical health of all individuals involved. The court shall not consider conduct of a present or proposed custodian that does not affect his relationship to the child. $H$. Krause, $\mathbf{n} 6$ above at 249 .

4t Weitzman, n 15 above at 231.

45 Cal Civ Code, Sec 4600 (West 1983).

16 In Re Marriage of Wood, 141 Cal App 3d 671, 683-84, 190 Cal Rptr, 469, 477-8 (1983).

47 'Family Law in the Fifty States', $n 7$ above, Table IX at 520.

48 Weitzman, $\mathrm{n} 15$ above at $49-50$.

49 Cal Civ Code Sec 4600(d) (West Supp 1989).

so See generally Weitzman, n 15 above at $247-57$; Chambers, 'Rethinking the Substantive Rules for Custody Disputes in Divorce', 83 Mich L Rev 477 (1984); Singer and Reynolds, 'A Dissent on Joint Custody', 47 Md L Rev 497 (1988).

${ }^{51}$ Chambers, $\mathrm{n} 50$ above at 562 . The author contends that there is no reason, based on gender alone, to prefer placing the child with the mother. The author gives an argument for placing the child with the primary caretaker without regard to gender. Id at 528. This theory argues that because a child forms a strong, special bond with the primary parent, custody with that parent should be preferred. The author also points out, however, that this position may fail to consider the strong attachment a child forms with the secondary caretaker as well. Id at 534-7.

52 Chambers, $n 50$ above at 527.

53 Pikula v Pikula, 374 NW 2d 705 (Minn 1985).

st Garska v McCoy, 278 SE 2d 357 (W. Va. 1981).

${ }^{55}$ Atkinson, 'Criteria for Deciding Custody in the Trial and Appellate Courts', 18 Fam L Q 1, 9 (1984).

${ }^{56}$ Ziff, 'The Primary Caretaker Presumption: Canadian Perspectives on An American Development', 4 Int Jo Law \& Fam 186 (1990).

57 See Michael M. v Superior Court of Sonoma County, 450 US 464.

58 M. Mead, Male and Female, 197 (1949).

${ }^{59}$ One team of psychologists, Parke and Sawin, observed fathers feeding their threc-year-olds. They observed that fathers respond to their infant's cues by adjusting the pace of feeding or the intensity of play - just as mothers do. They also observed that they rarely use this skill. When asked to demonstrate their competence for a researcher, fathers performed well, but under normal circumstances, most yield caretaking responsibility to their wives. R. Parke, D. Sawin, 'The Family in Early Infancy', in F. A. Pederson (ed) The Father-Infant Relationship (New York: 1980).

${ }^{60}$ Very few, if any, researchers would claim there are no differences between the responses of mothers and fathers to children, even if these responses are considered minor, eg, Michael Lamb found that fathers engaged infants in more rough-and-tumble play and invented new and unusual games. Mothers were more inclined to conventional games such as peek-a-boo and pat-a-cake. Lamb, 'Father-infant and mother-infant - Interaction in the first year of life', 48 Child Development (1977), 167-81. See also Berman, 'Are Women More Responsive Than Men to the Young? A Review of Developmental and Situational Variables', 88 Psychological Bull 668. This article reviews almost sixty studies over twenty years. This research takes many forms including measuring the pulse rate of mothers and fathers in response to pictures and observations of real interactions between mothers, fathers and children.

${ }^{61}$ R. Parke, D. Sawin, 'The Family in Early Infancy', in F. A. Pederson (ed) The Father-Infant Relationship (1980).

${ }_{62}$ S. Freud, An Outline of Psychoanalysis 48 (1949). Latter-day Freudians are strongly committed to mothers over fathers. Erik Erikson claimed that women have a biological, psychological, and ethical commitment to take care of human infancy, Erikson, 'Inner Space and Outer Space: Reflections on Womanhood', 93 Daedalus 582, 586 (1964), and Margaret Mahler describes the primary experience of infancy as that of separation, individuation from the mother (5-36 months). See Mahler, Pine, \& Bergman, The Psychological Birlh of the Human Infant (1975).

${ }^{63} 77$ Misc at 181, 350 NYS 2d, 289.

64 Id at 182, 290.

${ }^{65}$ For discussions of the imbalance of the female workload versus the male workload see $S$. Beck, The Gender Factory 7-10 (1985); Pleck, 'Men's Family Work: Three Perspectives and Some New Data', 25 Fam Coordinator 481, 487 (1979), Liefland, 'Career Patterns of Male and Female Lawyers', 35 Buffalo L Rev 601, 607-8, 613-17 (1986).

${ }_{66}$ Between 1973 and 1985 the average weekly income of the typical worker fell by 13 per cent. Frank Levy, 'Actually we are all growing poorer', New York Times, 3 May 1987.

${ }^{67}$ See $n 65$ above.

${ }^{68}$ Polikoff, 'Why Mothers are Losing', 7 Women's Rts L Rep 235 (1982). 
69 Weitzman, n 15 above at 232, found no significant difference in custody awards to mothers about 90 per cent four years after the abolition of the maternal preference presumption.

${ }^{70}$ Foster and Freed, 'Law and the Family: Politics of Divorce Process-Bargaining Leverage, Unfair Edge', $192 N Y L$ Sch J 6 (1984).

${ }^{71}$ Weitzman, n 15 above at 310-11, reports that about one-third of divorced women said that their husbands threatened to ask for custody as a ploy in negotiations. Men see custody as part of a total package of divorce issues that are, to some extent, all up for grabs. Women, by contrast, draw a line when it comes to custody. They are more likely to consider custody on an altogether different level - it is something they simply cannot negotiate because it is too important - it is worth any price.

${ }_{72}$ The House of Representatives did not amend Title VII-Bill to prohibit sex discrimination until only two days before voting on it. Until then, the Title VII did not mention sex at all: The intolerable practice of failing or refusing to hire a qualified job applicant or otherwise discriminating against an employee as to compensation, terms, conditions, and privileges of employment solely because of race, colour, religion, or national origin . . . is wrong and must be made legally wrong. HR 7152, 88th Cong, 2d Sess, 110 Cong. Rec 2705, 2732-3, 2804-5 (1964).

${ }^{73} 29$ USC Sec 206(d)(1)(1982)(EPA). The EPA is an amendment to the Fair Labor Standards Act, 29 USC Sec 201-19 (Supp. 3 1986).

${ }^{74}$ See below notes 81-2, for discussion of the persistent wage gap between men and women.

7542 USC Sec 2000e 2(a) (West 1988).

${ }^{76} \mathrm{M}$. A. Mason, The Equality Trap (1988). In this book, I discuss the limitations of Title VII and the EPA in dealing with female dominated occupations. These laws were enacted to force entry into male occupations, not to aid women who work in female occupations. In a sense these two pieces of legislation are conservative in nature since they require no structural changes in the workplace, such as pregnancy leaves or institutionalized part-time work, but simply permit women to compete in the existing structure. See generally chapters 1,4 , and 5 .

77 In a trio of 1989 decisions, the Supreme Court altered this trend with three cases that somcwhat narrowed the scope of Title VII, particularly with regard to affirmative action. Richmond v Croson, 109 S Ct 706 (1989), Wards Cove Packing Co v Atonio, 109 S Ct 2115 (1989) and Martin v Wilks 109 S Ct 2180 (1989).

${ }^{78}$ See generally Norton, 'Equal Employment Law: Crisis in Interpretation - Survival Against the Odds', 62 Tulane Law Review, 681 (1988). Title VII expressly states that preferential treatment is not required merely because of statistical imbalance with a group of employees compared to the available work force (see 703(j)). See also: Texas Dept of Community Affairs v Burdine, 450 US 248. Employer is under no obligation to hire a woman to balance the ratio between the sexes, nor to establish that the male hired is more qualified than the female not hired, nor to hire the female rather than an equally qualified male.

79109 S Ct 1775 (1989).

80 Id at 1790 . The court disagreed as to whether this shifting of the burden to the defendant was following precedent or taking a new turn. The plurality stated it was not a new interpretation, while O'Connor J, in a concurring opinion, stated: 'McDonnell Douglas and Burdine assumed that the plaintiff would bear the burden of persuasion as to both these attacks, and we clearly depart from that framework today. Such a departure requires justification, and its outlines should be clearly drawn'. Id at 1801 (O'Connor J, concurring). O Connor J went on to note that before the burden of proof could be shifted to the employer, 'the plaintiff must produce evidence sufficient to show that an illegitimate criterion was a substantial factor in the particular employment decision such that a reasonable factfinder could draw an inference that the decision was made "because of" the plaintiff's protected status'. Id at 1805.

81 See, 'Pay Equity or Pay Up: The Inevitable Evolution of Comparable Worth Into Employer Liability Under Title VII', 21 Loyola LAL Rev 305, 306 n 2 (1987) [hereinafter 'Pay Equity or Pay Up'].

${ }^{32}$ In 196023 million women were in the workforce; in 1986, 52 million were participating. $B$. Bergmann, The Economic Emergence of Women, at 20.

${ }^{83}$ See, 'Pay Equity or Pay Up', n 81 above, 306-7, n 3.

${ }^{81}$ US Dept of Commerce, Bureau of the Census, Women in the American Economy 15 (Nov 1986). 50.7 per cent of all women work in only nineteen of 503 occupational categories listed by the Department of Commerce. Id at 18, Table 8. All except three of the nineteen occupations in which women are concentrated are 60 per cent or more female and fifteen of the nineteen predominantly female occupations pay in the bottom half of 421 ranked earnings. Id at 23.

85 Below nn 97-105 and accompanying text. 
${ }^{86}$ See, 'Pay Equity or Pay Up', n 81 above at 314.

${ }^{87}$ See $\mathrm{n} 84$ above.

88 B. Bergmann, $n 82$ above at 25 Table 2-3 (1986).

89 There is a lively debate on this subject. See H. Aaron and C. Lougy, The Comparable Worth Controversy 13-15 (1986), M. A. Mason, The Equality Trap, see n 76 above, ch 5.

${ }^{90} 452$ US 161 (1981).

91 Id at 166.

92 Coming Glass Works v Brennan, 417 US 188, 195 (1971). To be actionable under the EPA, sexbased wage discrimination must occur within a single establishment. 29 GFR Sec 800.110.

${ }^{93}$ International Brotherhood of Teamsters v United States, 431 US 324, 335 n 15 (1977).

${ }^{94}$ Id.

95 See Griggs v Duke Power Co, 401 US 424, 432 (1971). The Griggs Court stated that: 'good intent or absence of discriminatory intent does not redeem employment procedures that operate as "headwinds" for minority groups'.

${ }_{96}$ Pouncy v Prudential Ins Co, 668 F 2d 795, 799 (5th Cir 1982). In Poungy, the court stated: 'This theory of recovery under Title VII is used to attach employment criteria that are facially neutral yet fall more harshly on a protected class of employees'.

${ }_{97}$ County of Washington v Gunther, 452 US at 180-1.

${ }^{98}$ Id at $166 \mathrm{n} 8$.

99 AFSCME v Washington, 578 F Supp 846, 864 (SD. Wash. 1983), rev'd, 770 F 2d 1401 (9th Cir 1985). The Court held that, under a disparate impact theory, the objective facially neutral practice was the defendant's system of compensation. Id. The Court found that 'the evidence is overwhelming that there has been historical discrimination against women ... and that discrimination has been, and is manifested by direct, overt, and institutionalized discrimination'.

${ }^{100}$ AFSCME v Washington, $770 \mathrm{~F} 2 \mathrm{~d} 1401,1405$ (9th Cir 1985). The Circuit Court of Appeals emphasized that 'the decision [of the State of Washington] to base compensations on the competitive market, rather than on a theory of comparable worth involves the assessment of a number of complex factors not easily ascertainable, an assessment too multifaceted to be appropriate for a disparate impact analysis.' Id at 1406 (citing Spaulding v University of Washington, 740 F 2d 686, 708 (9th Cir 1984)).

101 Id at 1408.

102 Colby v J. C. Penney Co, 811 F 2d 1119, 1126 (7th Gir 1987), American Nurses Association v Illinois, 783 F 2d 716, 726, 727 (7th Cir 1986).

${ }^{103}$ American Nurses v Illinois, $783 \mathrm{~F} 2 \mathrm{~d}$ at 726, 727.

${ }^{104}$ Colby v J. C. Penney, $811 \mathrm{~F} 2 \mathrm{~d}$ at 1126.

${ }^{105}$ See $n 72$ above.

${ }^{106}$ See discussion of integration theory, $\mathrm{nn} 86,87$ and accompanying text.

107 Arguably, if one turned around the language of Title VII, comparable worth may be seen as reverse discrimination since the effect of reclassifying jobs has a disparate impact on men. It can also be argued that reclassification constitutes disparate treatment since the intention of reclassification is to boost low paying women's jobs.

108 County of Washington v Gunther, 452 US 161 . The County of Washington conducted internal and external studies which indicated that female prison guards should be paid 95 per cent of the salary paid to male correction officers, yet the county paid females 70 per cent of their job's value and the men 100 per cent. Id at $180-1$. The court here decided that the county had violated its own salary survey and discriminated by treating men more advantageously than women. Id.

109 'Pay Equity or Pay Up', n 81 above at 315.

110 Id. For a thorough discussion of the economic controversies regarding wage setting and free market theories see generally, F. Morris, J. O'Neill, J. Calhoon, J. Sloan, S. Mitchell, and T. Fahner, Judicial Wage Determination ... A Volatile Spectre: Perspectives on Comparable Worth (1984).

111 House Bill 41, Pay Equity Technical Assistance Act.

112 Wage Justice, 41.

${ }^{113}$ States with pay equity policies include Hawaii, Iowa, Maine, Michigan, Minnesota, Montana, Ohio, Oregon, Washington, Wisconsin. 'Pay Equity or Pay Up', n 81 above at 362 n 360 . As of 1987, only Arkansas, Georgia and Idaho have taken no action at all on this issue at the state level. S. Evans and B. Nelson, Wage Justice 4.

114 The following states have pay equity studies: Arizona, California, Hawaii, Illinois, Indiana, Iowa, Kansas, Kentucky, Louisiana, Maine, Maryland, Massachusetts, Michigan, Minnesota, Montana, Nebraska, New Jersey, New Mexico, North Carolina, Ohio, Oregon, Rhode Island, 
Vermont, Washington, West Virginia, Wisconsin, and Wyoming. See, 'Pay Equity or Pay Up', n 81 , at $362 \mathrm{n} 361$ and accompanying text.

115 Id at 363 n 370 . Of the ten states which have pay equity policies, seven were established by legislation, two by administrative policy and one by executive order.

116 For a complete discussion, Minnesota's experience in passing comparable worth laws, Evans and Nelson, see $\mathrm{n} I 13$ above at $69-91$.

117 Id at 159.

118 Id.

119 It is estimated that 85 per cent of all working women will become pregnant during their working life. Dowd, 'Maternity Leave: Taking Sex Differences Into Account', 54 Fordham L Rev 701 (1986).

120 Since 1948, the Bureau of Labor Statistics has set a standard of thirty-five hours per week to distinguish full-time work from part-time work. Bureau of the Census, US Dept of Commerce, Current Population Reports, Series P-50, No 3, at 1 (21 Jan 1948).

${ }^{121}$ Chamallas, 'Women and Part-Time Work: The Gase for Pay Equity and Equal Access', $64 \mathrm{~N}$ $C L \operatorname{Rev} 709,715$ (1986).

122 Women's Bureau, Office of the Secretary, US Dept of Labor, Bulletin No 298, Time of Change: 1983 Handbook on Women Workers 36 (1983) at 37, 38 [hereinafter Handbook on Women Workers].

${ }^{123}$ Mellor and Stamas, 'Usual Weekly Earnings: Another Look at Intergroup Differences and

Basic Trends', 105 Monthly Lab Rev 15, 21 (April 1982).

${ }^{124}$ Chamallas, $\mathrm{n} 121$ above at $715 \mathrm{n} 32$.

${ }_{125}$ See Handbook of Women Workers, $\mathrm{n} 122$ above at 37-8.

126 Chamallas, $\mathrm{n} 121$ above at 718-19.

127 Heffernan, 'Employee Benefits', 1 Fam Eco Rev 6, 10 (1985).

128 In 1981 women constituted 69 per cent of the part-time work force. Part-time workers are paid

51 per cent of full-time male workers. Chamallas, n 121 above at 714-15, note 60 .

${ }_{129}$ Between 1973 and 1985 the average weekly income of the typical worker fell by 13 per cent.

Levy, 'Actually We Are All Growing Poorer', New York Times 3 May 1987 (Business) at 2.

${ }^{130}$ Nearly half of all marriages entered into today are projected to end in divorce. Weitzman, $n 15$ above, at xvii.

131 See discussion on comparable worth and notes 89-118 above.

132 Coming Glass Works v Brennan, 417 US 188, 195 n 92 (1971).

13329 USC A Sec 206(d)(1)(West 1982).

13129 CFR Sec 1620.26 (1988). This interpretation covers temporary workers as well as parttime workers. The interpretation uses one month of employment as a rule of thumb to determine whether employment is in fact temporary.

${ }_{135}$ Chamallas, $\mathrm{n} 121$ above at 740 .

${ }^{136}$ New interpretation which would have deleted part-time and temporary defenses was proposed by the Carter Administration, but never adopted. Chamallas, $n 121$ above at 739 n 175, 740 n 176.

${ }^{137}$ County of Washington v Gunther, 452 US 161, 168-71 (1981). '[I]ncorporation of the fourth affirmative defense could have significant consequences for Title VII litigation. Title VII's prohibition of discriminatory employment practice was intended to be broadly inclusive . . The fourth affirmative defense of the Equal Pay Act, however, was designed differently, to confine the application of the Act to wage differentials attributable to sex discrimination ... Although we do not decide ... how sex-based wage discrimination litigation under Title VII should be structured to accommodate the fourth affirmative defense of the Equal Pay Act, we consider it clear that the Bennett Amendment [to Title VII], under this interpretation, is not rendered superfluous.' Id at 170-1.

${ }^{138}$ Evans and Nelson, n 113 above at 142-4.

${ }^{139}$ See discussion on comparable worth and the courts, notes 89-118 above and accompanying text.

${ }^{140}$ Chamallas, $\mathrm{n} 121$ above, 717 at note 47.

141 Id at 723, note 90, citing Federal Employees Part-time Career Employment Act of 1978, 5 USC 3401-8 (1982).

${ }_{142}$ A great media controversy was generated upon the publication of F. N. Schwartz, 'Management Women and the New Facts of Life', Harvard Business Review, Jan-Feb 1989, at 65. Schwartz reviews the failure of management women to combine motherhood and career and suggests a reduced hour track, or 'Mommy Track'.

${ }^{143}$ In California, the California State Bar's Committee on Women in the Law has taken up the 
issue of part-time employment for women with children. In a survey of Los Angeles firms with more than twenty attorneys, eleven firms have women working half to three-quarters time. These were accommodations on an individual basis, not a general firm policy. The criterion was that the woman has previously been a valued employee or was considered to be someone very special. The Recorder, 25 April, 1986, 1, col 4.

${ }^{144} \mathrm{~J}$. Kingson, 'Women in the Law Say Path is Limited by "Mommy Track", New York Times, 8 August, 1988, p 1, col 5.

145 The New York City Board of Education, which has offered paternity leaves since 1973, regularly grants about two thousand leaves each year to mothers and four or five leaves to fathers. Degler, $n 5$ above at 466 .

${ }_{146}$ See $\mathrm{n} 141$ above.

${ }^{147}$ Amicus brief by NOW and NWPC among others. See $\mathrm{n} 000$ above.

${ }_{148}$ Pregnancy Discrimination Act, Civil Rights Act of 1964, sec 701 et seq, 701(k) as amended, 42 USC 2000 (e) et seq, 2000(e) et seq, 2000e(k). The amendment provides, in part: 'The terms "because of sex" or "on the basis of sex" include, but are not limited to, because of or on the basis of pregnancy, childbirth, or related medical conditions; and women affected by pregnancy, childbirth, or related medical conditions shall be treated the same for all employment-related purposes . . a as other persons not so affected but similar in their ability or inability to work . . ' Id.

149 See notes 58-60 and accompanying text.

150 In Cal Fed Savings v Guerra, 479 US 272 (1987).

The dispute was over the right of return to the same or comparable job after four months' maternity leave. This right of return was not guaranteed for disabilities.

151 Sweden provides a model of parental leave that includes substantial income maintenance. Each family is allowed a nine-month leave (to be taken by the mother or father, or split between them) at 90 per cent pay, and an additional three months at a further reduced rate of pay. Mason, The Equality Trap, $\mathrm{n} 6$ above at 138.

${ }_{152}$ This is the same approach as Title VII which allows women to compete with men on a male model. See discussion on Title VII limitations: $\mathrm{Nn} 76-82$ and all accompanying text.

153 See A. Kessler Harris, Out to Work: A History of Wage Eaming Women in the Uniled States, 234-5, 254-9, 296-7 (I982).

154 L. Finley, "Transcending Equality Theory: A Way Out of the Maternity and Workplace Debate', 86 Cal L Review 1118 at 1124.

15542 USC $2000 \mathrm{e}(\mathrm{k})$ (1982).

156 Finley, n 154 above at 1125.

157 Id at 1126.

138417 US 484 (1974).

At issue in Geduldig was California's disability insurance programme for private employees who were temporarily disabled by an injury or illness not covered by workers' compensation. The plan was challenged on equal protection grounds because it excluded disabilities attributable to normal pregnancies. The Supreme Court upheld the plan's constitutionality, finding that ' $[t]$ here is no evidence in the record that the selection of the risks insured by the program worked to discriminate against any definable group or class in terms of the aggregate risk protection derived by that group or class from the program'. Id at 496.

159429 US 125 (1986).

This case involved an insurance plan similar to the disability plan in Geduldig, but the challenge was based on a claim of discrimination under Title VII. The Court held that Geduldig was on point in holding that 'an exclusion of pregnancy from a disability-benefits plan providing general coverage is not a gender-based discrimination at all.' Id at 136. The plan withstood the Title VII challenge. Id at $145-6$.

160 Guerra, 272 US at 289. For discussion of this decision see notes $147-50$ and accompanying text.

161 Parental Leave Act, Senate Bill 951 (DeConcinci, 9 May 1989).

162 In addition to the paid leave provided by the Swedish system (see, n 151 above), parents are allowed up to sixty days per year to stay with a sick child, and parents with children under eight may work a six-hour day, at a corresponding reduction in pay. Mason, n 76 above at 138.

163 Mason, $\mathrm{n} 76$ above at 130 .

164 Id 124. The male-female wage gap has not narrowed in the United States over the last twenty years as much as it has in other industrial countries. For a discussion of the progress made in other countries, see S. Hewlitt, A Lesser Life, 73 (1986). 
165 Most feminist theorists who tackle the problem of children resolve it as an equal burden between mother and father and therefore not an impediment to an equal rights approach. See B. Friedan, The Second Stage 112 (1981).

${ }_{166}$ Civil Rights Commission Report, as quoted in Newsweek, 15 July, 15 42, 42. 